\title{
BIBLIOGRÁFIA
}

\section{A magyar nyomda-, könyv-, sajtó- és könyvtártörténeti szakirodalom 2013-ban}

Röviditések:

\begin{tabular}{|c|c|}
\hline EgyKönyvÉvk & = Az Egyetemi Könyvtár Évkönyvei \\
\hline GeodKart & $=$ Geodézia és Kartográfia \\
\hline $\mathrm{HK}$ & $=$ Hadtörténelmi Közlemények \\
\hline It & $=$ Irodalomtörténet \\
\hline ItK & $=$ Irodalomtörténeti Közlemények \\
\hline $\mathrm{KF}$ & = Könyvtári Figyelő \\
\hline KKK & = Könyv, Könyvtár, Könyvtáros \\
\hline $\mathrm{KN}$ & $=$ Könyv és Nevelés \\
\hline MG & $=$ Magyar Grafika \\
\hline MKsz & $=$ Magyar Könyvszemle \\
\hline MNyelv & $=$ Magyar Nyelv \\
\hline MTud & = Magyar Tudomány \\
\hline MVízjel & $=$ Magyar Vízjel \\
\hline MűvtörtÉrt. & $=$ Mủvészettörténeti Értesítő \\
\hline Esemény és narratíva... & $\begin{aligned}= & \text { Esemény és narratíva. Történetiség, elbeszélés(ek), interpretáció / } \\
& \text { szerk. KöTÉL Emőke, RAINER M. János. Bp.: Bibl. Nationalis Hunga- } \\
& \text { riae-Gondolat, 2013. } 320 \text { p. ill. (Bibliotheca scientiae \& artis) }\end{aligned}$ \\
\hline Magyar sajtószabadság... & $\begin{aligned} & \text { = } \text { Magyar sajtószabadság és -szabályozás, 1914-1989. Elöadások } \\
& \text { a magyar sajtószabadság történetéhez. Budapest, 2012. novem- } \\
& \text { ber 15. / szerk. PAÁL Vince. Bp.: Médiatudományi Int., 2013. } 98 \text { p. } \\
& \text { (Médiatudományi könyvtár; 6.) }\end{aligned}$ \\
\hline $\begin{array}{l}\text { Nyelv, lelkiség } \\
\text { és regionalitás... }\end{array}$ & $\begin{aligned}= & \text { Nyelv, lelkiség és regionalitás a közép- és kora újkorban. Előadások } \\
& \text { a VII. Nemzetközi Hungarológiai Kongresszuson. Kolozsvár, } 2011 . \\
& \text { augusztus 22-27. / szerk. GÁBOR Csilla et al. Kolozsvár: Egyetemi Mü- } \\
& \text { hely K.-Bolyai Társ., 2013. } 599 \text { p. ill. (A VII. Nemzetközi Hungaro- } \\
& \text { lógiai Kongresszus kiadványai) }\end{aligned}$ \\
\hline $\begin{array}{l}\text { Nyolcszáz esztendős } \\
\text { a ferences rend... }\end{array}$ & $\begin{aligned}= & \text { Nyolcszáz esztendős a ferences rend. Tanulmányok a rend lelkisé- } \\
& \text { géről, történeti hivatásáról és kulturális-müvészeti szerepéről / szerk. } \\
& \text { MedGYESY S. Norbert, ÖTVös István, Öze Sándor. Bp.: Írott Szó Ala- } \\
& \text { pítvány-M. Napló, 2013. (Művelődéstörténeti műhely. Rendtörténeti } \\
& \text { konferenciák; 8.) 1-2. köt. } 1314 \text { p. }\end{aligned}$ \\
\hline
\end{tabular}


Szín, játék, költészet... = Szín, játék, költészet. Tanulmányok a nyolcvanéves Kilián István tiszteletére / szerk. Czibula Katalin, Demeter Júlia, Pintér Márta Zsuzsanna. Nagyvárad: Partium; Bp.: Protea Egyes.-Reciti, 2013. 448 p. ill.

\section{Általános és összefoglaló munkák, elvi kérdések}

Antal Alexandra: A bécsi Magyar Hírmondó mecenatúrájának müködéséről. Görög Demeter levelei gróf Széchényi Ferenchez = MKsz (129.) 2013. 4. 484-488.

Bitai Judit - Hegedüs Éva: A muzeális állomány feltárása a Pannonhalmi Főapátsági Könyvtárban $=$ Collectanea Sancti Martini (1.) 2013. 1. 353-362.

FAZAKAS Gergely Tamás: A kora újkori magyarországi imádság- és meditációirodalom kutatásának legújabb eredményei és tendenciái $=$ Studia Litteraria (52.) 2013. 3/4. 266-287.

GÁbORJÁNI SzABÓ Botond: A könyv, az olvasás és Debrecen „magánál nagyobb” híre = A debreceni népmüvelö-könyvtáros képzés jubileumi évkönyve, 1963-2013: 50 év / szerk. Goda Éva, Suppné Tarnay Györgyi. Debrecen: Debreceni Ref. Hittud. Egy., 2013. 69-78.

HAUSNER Gábor: Márs könyvet olvas. Zrínyi Miklós és a 17. századi hadtudományi irodalom. Bp.: Argumentum, 2013. 219 p. (A Hadtörténeti Intézet és Múzeum könyvtára)

Héder Mihály - LÁng Benedek - Lévai Szabolcs: Filológiai okok egy monoalfabetikus titkosírásfejtő szoftver mellett. A program müködése és tapasztalatai $=$ MKsz (129.) 2013. 4. 511-519. ill.

KAKASY Judit: Magyar könyvajándék a könyvtáros pápának, XI. Piusznak = EgyKönyvÉvk (16.) 2013. 207-220. ill.

KarVALICs László, Z.: Megújíthatja-e az információs nézőpont az írástörténet-írást? = Századvég 2013. 4. Írástörténet. 5-26.

Keszeg Vilmos: Könyvdedikálás a kommunizmus éveiben $=, \ldots$ hogy legyen a víznek lefolyása..." . Köszöntő kötet Szilágyi N. Sándor tiszteletére / szerk. BENÖ Attila, FAZAKAS Emese, KÁDÁr Edit. Kolozsvár: Erdélyi Múzeum-Egyes., 2013. 247-258.
Lexicon Latinitatis medii aevi Hungariae / praeses consilii editionem adiuvantis János HARMATTA; ad redigendum edendumque consilio adiuverunt Loránd BENKÖ et al.; ad edendum praeparavit Iván BoronKAI; ab Instituto Studiorum Antiquitatis Promovendorum Academiae Scientiarum Hungaricae compositum $=$ A magyarországi középkori latinság szótára / a szerkbiz. elnöke HARMATTA János; szerkbiz. BEnKő Loránd et al.; kiadásra előkész. BoronKAI Iván; kész. az MTA Ókortudományi Kutatócsoportjában. Bp.: Akad. K., 1987-

Suppl. 1. A-I / adiuv. Ibolya Bellus et al. 2013. 283 p.

Mikó Árpád: A Corvinusok Budán. Római nevek a müvészet játékterében $=$ Kö kövön. Dávid Ferenc 73. születésnapjára / szerk. SzENTESi Edit, Mentényi Klára, Simon Anna. Bp.: Vince K., 2013. 2. köt. 565-574. ill.

MoNOK István: Magyar, múvelődéstörténeti és lexikon = Történelmi Szle (55.) 2013. 4. 657-665.

PAPP Kinga: Kálnoki Sámuel és a könyvek világa = Erdélyi Múzeum (75.) 2013. 1. 16-26.

TокАл Zsolt: A kínai könyv története $=$ Zhongguo tushu shi. Bp.: Quattrocento, 2013. 135 p. ill.

То́тн Gergely: A magyar történetírás kritikája és megújulásának programja az 1740-es évekből. Bél Mátyás és a Scriptores rerum Hungaricarum = Történelmi Szle (55.) 2013. 4. 593-617.

\section{Bibliográfiák, repertóriumok, katalógusok}

Ave Tyrnavia! Opera impressa Tyrnaviae Typis Academicis, 1648-1777 / Stephanus KäFER, Esther KovÁcs. Budapestini-Strigonii-Tyrnaviae: Esztergomi Hittud. Főisk. etc., 2013. 287 p. ill.

BiBor Máté János: Wehli Tünde megjelent müvei, 1975-2013 = Ars Hungarica (39.) 2013. 2. 
Liber decorum. Wehli Tünde köszöntése 2. 242-262.

BuncsÁK Katalin Julianna: A Szepes vármegyei Teplic papírmalom a szakirodalomban = MVízjel (11.) 2013. 25. 47-49.

Catalogue of the incunables in the Library and Information Centre of the Hungarian Academy of Sciences (Magyar Tudományos Akadémia Könyvtár és Információs Központ) / comp. by Marianne Rozsondai and Béla RozsondaI. Bp.: Argumentum-Libr. of the HAS, 2013. 458 p., 16 t. ill.

Cimélia - könyvkincsek. Régi és ritka könyvek a Somogyi-könyvtár gyüjteményében. Kiállítás a Somogyi-könyvtárban, 2013. július 16-október 9. / rend., ism., szerk. SzÖKEFALVI-NAGY Erzsébet. Szeged: Somogyi-kvt., 2013. 55 p. ill.

Csillagászat-történeti tudásvagyon. Kiállítás az ELTE Egyetemi Könyvtár csillagászati kézirataiból és nyomtatványaiból. 2013. október 29-2014. március 28. = Accumulated European knowledge of astronomical history. Exhibition of astronomical manuscripts and prints of ELTE University Library. 29 Oktober 2013-28 March 2014 / írta és rend. Knapp Éva. Bp.: Egy. Kvt., 2012. 164 p. ill. (Kiállítások az ELTE Egyetemi Könyvtárban; 7.)

Friss Újság Színes Regénytára / szerk. GRóB László. Máriabesnyő: Attraktor, 2013. 89 p. ill. (A magyar ponyva képes bibliográfiája; 5.)

HegyKöZI Ilona - Kollár Mária: A magyar nyomda-, könyv-, sajtó- és könyvtártörténeti szakirodalom 2012-ben = MKsz (129.) 2013. 4. 494-510.

A magyar sajtótörténet válogatott bibliográfiája, 1705-1944 / összeáll. LAKATOS Éva. Bp.: OSZK, 2010-2013.

4. köt. Sze-Z. 2013. XIII, 347 p.

Palladis Félpengős regények / szerk. GRóв László. Máriabesnyő: Attraktor, 2013. 106 p. ill. (A magyar ponyva képes bibliográfiája; 2.)

Pécs Város Közművelődési Könyvtárától a Csorba Győző Könyvtárig. 70 éves a közmüvelödési könyvtár Pécsett, 1943-2013 / összeáll. GyÁnti István, Katona Anikó, Szabolcsiné Orosz Hajnalka. Pécs: Csorba Gy. Kvt.,
2013. 175 p. ill. (Csorba Győző Könyvtár kiadványai; 1.)

Tarka Regénytár / szerk. GróB László. Máriabesnyő: Attraktor, 2013. 113 p. ill. (A magyar ponyva képes bibliográfiája; 6.)

Távol az Araráttól. Örmény kultúra a Kárpátmedencében. A Budapesti Történeti Múzeum és az Országos Széchényi Könyvtár közös kiállítása. 2013. április 5-2013. szeptember 15. / rend., kat. szerk. Kovács Bálint, PÁl Emese. Bp.: BTM-OSZK, 2013. 184 p. ill. Angol nyelven is

\section{Cenzúratörténet és más jogi szabályozások}

Buzinkay Géza: Sajtóreform 1914-ben = In Medias Res (2.) 2013. 1. 1-21.

DEÁK Ágnes: „... hová jutottunk, midőn egy conservativ és kath. szerkesztőt ilyen zsidóügyi cikkért elítélnek". Lonkay Antal és az Idők Tanúja sajtópere 1863-ban = Homályzónák. Felvilágosodás és liberalizmus. Tanulmányok Kecskeméti Károly 80. születésnapjára / föszerk. Borsi-KÁLMÁn Béla. Bp.: Sík K., 2013. 141-152.

HoRvÁTH Attila: A cenzúra müködési mechanizmusa Magyarországon a szovjet típusú diktatúra időszakában = Magyar sajtószabadság... 80-98.

KLEIN Tamás: Adalékok a Horthy-korszak sajtórendészeti szabályozásához. 2. Sajtószabadság és/vagy nemzetérdek - egy „öncélú nemzeti állam" sajtószabályozása, 19311936 = In Medias Res (2.) 2013. 1. 45-65.

LENGYEL András: A Népszava sajtórendészeti ellenőrzése, 1929 = A mindennapok szemüvegkészítoii. Sajtótörténeti tanulmányok / LENGYEL András. Bp.: Nap K., 2013. 321-353.

Magyar sajtószabadság és -szabályozás, 1914 1989. Előadások a magyar sajtószabadság történetéhez. Budapest, 2012. november $15 . /$ szerk. PAÁl Vince. Bp.: Médiatudományi Int., 2013. 98 p. (Médiatudományi könyvtár; 6.)

Marschal Adrienn: A diktatúra Szabad Szája. Politikai vicclapok 1945-1956 = Utak és útkereszteződések. Ünnepi tanulmányok M. Kiss Sándor tiszteletére / föszerk. KAH- 
LER Frigyes; szerk. BANK Barbara. Bp.: Történelmi Ismeretterjesztő Társulat Egyes., 2013. 513-522.

NAGY Gábor: Szovjet könyvrazzia a Debreceni Református Kollégium Könyvtárában: 1946. szeptember, Révész Imre püspök küzdelme [elektronikus dok.] = ArchivNet (12.) 2012. 4.

Elektr. hely és hozzáférés: http://www.archivnet.hu/politika/szovjet_konyvrazzia_a_debreceni_reformatus_kollegium_konyvtaraban. html?oldal=1

PAÁL Vince: Sajtószabályozás és sajtószabadság a Horthy-korszakban = Magyar sajtószabadság... 7-19.

Megjelent még: NMHH-évkönyv 2013. 147-160.

RÉvÉsz T. Mihály: Adalékok a sajtójogi kodifikáció 1945 utáni históriájához $=$ Rendszerváltások kortársa és kutatója. Tanulmánykötet Izsák Lajos 70. születésnapjára / főszerk. ERDŐDY Gábor. Bp.: ELTE Eötvös K., 2013. 269-275.

RÉvÉsz T. Mihály: A magyar sajtószabályozás kezdetei és hőskora = Jogtörténeti parerga. Ünnepi tanulmányok Mezey Barna 60. születésnapja tiszteletére / szerk. MÁтHÉ Gábor, RÉvÉsz T. Mihály, GoszTonyi Gergely. Bp.: ELTE Eötvös K., 2013. 301-312.

RÉvÉsz T. Mihály: Sajtószabályozás Magyarországon, 1945-1960 = Magyar sajtószabadság... 55-65.

Systematica collectio / sajtó alá rend. és a bevezetőt írta STEMPELy Irén. Piliscsaba: PPKE BTK, 2013. 94 p. (Pázmány irodalmi mühely. Források; 7.)

\section{Könyvtörténet \\ Kéziratosság, kódexek}

BALÁzs Mihály: Varsolci János és Rettegi János ismeretlen szövegeiröl = ItK (117.) 2013. 1. Bethlen Gábor - irodalom, vallás, tudományosság. 5-22.

Balla Tünde - Lakatos Attila: „Nagy keseredett sziuel az egész keresztyénségh eleyben teriesztetett”. Szalárdi János beszámolója Vá- rad 1660. évi ostromáról = „Várad várának, az pogány török által megh szállásárul...”. Szalárdi János emlékirata Várad 1660. évi veszedelméről / szerk., kísérő tan. BALLA Tünde, LAKATos Attila; a latin szövegeket ford. és gond. SzVORÉNYI Róbert. Bp.: OSZK; Nagyvárad: Partium, 2013. 173-218.

BENEI Bernadett: Krónikafolytatások a 13. század elején? Historiográfiai áttekintés $=$ Micae mediaevales III. Fiatal történészek dolgozatai a középkori Magyarországról és Európáról / szerk. GÁl Judit et al. Bp.: ELTE BTK Történelemtud. Doktori Isk., 2013. 117-131.

BiBor Máté János: Az Egyetemi Könyvtár Arany János kéziratai = EgyKönyvÉvk (16.) 2013. 223-248. ill.

Cleminson, Ralph: Two Slavonic manuscripts at Pannonhalma = Studia Slavica Acad. Scient. Hung. (58.) 2013. 2. 289-295.

DoncseCz Etelka: Szkíta Horatius és bécsi Sappho. Előtanulmány Batsányi János levelezésének készülő kritikai kiadásához = ItK (117.) 2013. 3. 281-318.

GeszTelyi Tamás: A Korvin-könyvtár Pliniuskódexe és a korabeli Plinius-ősnyomtatványok illuminációi = Antik Tan. (57.) 2013. 2. 271-285. ill.

HolLeR László: „Ki miatt ördögök szörnyülének és csodálkodván úgy szólának”. Kronológia és szövegrekonstrukciók. A 120 éve felfedezett Königsbergi Szalagok alapkérdéseiröl = Nyelvtud. Közl. (109.) 2013. 267-336.

Holler László: A veszprémi görög rítusú monostor alapító- és adománylevelének datálásról és további kérdéseiről. Megjegyzések Szentgyörgyi Rudolf tanulmányához = MNyelv (109.) 2013. 1. 50-67.

HuBERT Ildikó: Virágh Aloysia klarissza apácának írt tanítás 1734-ből = Nyolcszáz esztendős a ferences rend... 2. köt. 979-988.

JózsA Attila: A benedikcionále mint liturgikus könyvtípus = MEgyházzene (20.) 2012/ 2013. 3. 259-266.

JuHÁsz Szandra: Héber nyelvű bejegyzések a 16-18. századi amicorumokban = Filológia és irodalom. Tanulmányok a Pázmány Péter Katolikus Egyetem Irodalomtudományi Doktori Iskolájának Kárpát-medencei irodal- 
mi MA- és PhD-hallgatók számára rendezett Filológia és irodalom című konferenciáján elhangzott előadásokból / szerk. ToмPA Zsófia. Bp.: PPKE BTK, 2013. 137-164. ill. KerTÉsz Balázs: V. László-kori levél- és beszédgyüjtemény a Bajor Állami Könyvtár Clm 8482 jelzetü kódexében = Ars Hungarica (39.) 2013. 1. Liber decorum. Wehli Tünde köszöntése 1. 101-105. ill.

KeRTÉsz Balázs: A magyarországi obszerváns ferencesek krónikájának szerzőségéhez $=$ Nyolcszáz esztendős a ferences rend... 1. köt. 164-186.

Kocsis Mihály: The recently found folio of the Szeged Minea $=$ Studia Slavica Acad . Scient. Hung. (58.) 2013. 2. 387-390. ill.

KöRMENDY Kinga: Ulászló-graduále. Kérdések és lehetséges válaszok = Ars Hungarica (39.) 2013. 1. Liber decorum. Wehli Tünde köszöntése 1. 114-123.

KovÁcs Andrea: A Csíksomlyói Cantionale = Nyolcszáz esztendős a ferences rend... 1. köt. 547-574. ill.

KöVÁRI Réka: A Deák-Szentes kézirat $=$ The Deák-Szentes manuscript. Ford. PoKOLY Judit. Bp.: Magyarok Nagyasszonya Ferences Rendtartomány-MTA Bölcsészettudományi Kutatóközp., 2013. 364 p. ill. (Fontes historici Ordinis Fratrum Minorum in Hungaria; 6.)

KöVÁRI Réka: Népénekek Szentes Mózes kéziratában (1751-1752). Ferences énekek a földindulások ellen $=$ Nyolcszáz esztendős a ferences rend... 1. köt. 589-601. ill.

LATZKovits Miklós-Mándity Zorán: Pákei József album amicorumáról = Keresztény Magvető (118.) 2012. 4. 315-324.

LAUF Judit: A Sopronban őrzött liturgikus kódextöredékek és a Schottenstift = Ars Hungarica (39.) 2013. 1. Liber decorum. Wehli Tünde köszöntése 1. 124-135. ill.

MADAs Edit: Latin nyelvű forrásszövegek müfaji átalakulása a magyar nyelvü kódexirodalomban. Hugo a Sancto Caro sermója az Érsekújvári Kódexben $=$ Studia Litteraria (52.) 2013. 3/4. 20-33. ill.

MADAS Edit: A magyar „szent királyok” középeurópai kultusza liturgikus és hagiográfiai források tükrében = Ars Hungarica (39.)
2013. 2. Liber decorum. Wehli Tünde köszöntése 2. 145-152. ill.

Függelék: Szent István, Szent László és Szent Imre legendáit tartalmazó, külföldön készült vagy használt kódexek időrendben, őrzési helyük, eredetük és használatuk feltüntetésével Mıкó Gábor: Élt -e valaha Szent István fia, Ottó herceg? Egy ismeretlen 15. századi krónika tanúskodása $=$ Történelmi Szle (55.) 2013. 1. 1-22.

Mıкó Gábor: A középkori magyar királyok ismeretlen lajstroma Monoszlóy András könyvtárából = Acta Historica Acad. Scient. Hung. 2013. 135. 125-137.

NAGY Ilona, M.: A Margit-legenda hiányzó eleje és a Pray-töredék = Szín, játék, költészet... 227-233.

OLÁH Anna: Egy világraszóló tudományos életmű kézen-közön. Bolyai Farkas ,elsikkadt” kéziratainak százéves vándorútja kutatók, könyvtárak, országok között. Bolyai Farkas hö- és kemencetanja = Utórengések. A Bolyai Múhely Alapítvány és a Bolyai Önképző Mủhely évkönyve / szerk. BALÁzs Géza. Bp.: Bolyai Mühely Alapítvány, 2013. 8-28. ill.

Öтvös Zsuzsanna: A group of marginal notes from another textual tradition $=$ Byzanz und das Abendland. Begegnungen zwischen Ost und West / Hrsg. Erika JuHÁsz. Bp.: EötvösJózsef-Coll., 2013. 71-120. ill.

PAPp Ágnes: Retrospektív liturgikus-zenei forrásunk új megvilágításban. A 17. századi Medvedics-rituále $=$ MZene (51.) 2013. 4. 384-399. ill.

RADEK Tünde: Johannes de Utino „Világkrónikájának" kéziratai (14-15. század) és a német nyelvü kéziratok provenienciája $=$ MKsz (129.) 2013. 1. 1-22.

SÁNTHA Attila: Hamisítvány-e a Csíki székely krónika? [1-4.] = Székelyföld (17.) 2013. 1. rész: 9. 87-139.; 2. rész:10. 76-114. ill.; 3. rész: 11. Király László 70. 43-62.; 4. rész:12. 111-146. ill.

SCHÜSZLER Tamara: A manuscript from the library of Péter Váradi. Physical features = Byzanz und das Abendland. Begegnungen zwischen Ost und West / Hrsg. Erika JuHÁsz. Bp.: Eötvös-József-Coll., 2013. 353-357. ill. 
SpychaŁA, Lesłav: Kiegészítés „A magyar-lengyel vegyes krónika" kéziratos hagyományához. A „Krasiński 6. számú kódex” feltételezett szövege $=$ MKsz (129.) 2013. 4. 409-423.

SudÁr LÁsZlónÉ MolnÁR Zsuzsanna: Kiegészítés a Cronica Chepregiensis történetéhez = Vasi Honism. és Helytört. Közl. 2012. 2. 5-11.

SzIRÁKI Szilvia: A kolozsvári Ként kapáló szövegváltozatai $=$ Szín, játék, költészet... 276281. ill.

Sztulik-KNiesl Balázs: Preces germanicae pro singulis horis cum iconibus, avagy egy unikális képi-szöveges emlék a 17. századból $=$ Collectanea Sancti Martini (1.) 2013. 1. 29-48. ill.

VizKelety András: „Die Sultanstochter im Blumengarten" in einer ehemaligen Güssinger Handschrift. A szultánkisasszony a virágok közt. Verses novella egy Németújvárról elszármazott kódexben = Soproni Szle (67.) 2013. 4. Tanulmányok Mollay Károly születésének 100. évfordulójára. 440-453. ill.

Zsoldos Endre - Zsupán Edina: Stellarium. Egy csillagászati kódex Mátyás könyvtárában = Orpheus Noster (5.) 2013. 4. 64-87. ill.

Zvara Edina: Révai Miklós tudóstársaság-tervezetének újabb kézirata a kismartoni Esterházy-könyvtárban. Kiegészítések a tagjelöltek névsorához = ItK (117.) 2013. 5. 600-609.

\section{Nyomda-, nyomdászattörténet}

\section{Több évszázadot érintő munkák}

GÉcs Béla: Nyomdászattörténeti töredékek. Békéscsaba: Gécs B., 2013. 264 p. ill.

Verók Attila: Az Érseki Líceumi Nyomda = Az egri Domus Universitatis és Líceum. Oktatás, tudomány, művészet, 1763-2013 / szerk. Petercsák Tivadar. Eger: Líceum K., 2013. 190-202., 467-484. ill.

\section{5. század}

Borsa Gedeon: Andreas Hess. A képeket vál. FARKAS Gábor Farkas. Bp.: ArgumentumOSZK-MTA BTK Irodtud. Int.-MOKKA-R Egyes., 2013. 221 p. ill. (A Magyar Könyvszemle és a MOKKA-R Egyesület füzetei; 6.)

FrImMOVÁ, Eva: L'activité de l'imprimeur Andreas entre 1477 et 1480 à Presbourg = MKsz (129.) 2013. 4. 424-447.

16-17. század

BÁnfi Szilvia: Rheda Pál lipcsei kapcsolata = MKsz (129.) 2013. 4. 480-483. ill.

Az RMNy 959. tételéröl

\section{7. század}

BÁNFI Szilvia: Ki és mikor nyomtatta Debrecenben a budapesti Egyetemi Könyvtárban őrzött Jansonius-féle Biblia pótlólag újraszedett leveleit? = MKsz (129.) 2013. 3. 365-371. ill.

Perger Péter: M. Tótfalusi Kis Miklós örmény betűi = Távol az Araráttól. Örmény kultúra a Kárpát-medencében. A Budapesti Történeti Múzeum és az Országos Széchényi Könyvtár közös kiállítása. 2013. április 5-2013. szeptember 15. / rend., kat. szerk. KovÁCS Bálint, PÁL Emese. Bp.: BTM-OSZK, 2013. 44-51. ill.

18. század

EcSEDY Judit, V.: Zrínyi és a marosvásárhelyi nyomda $=$ MG (57.) 2013. 2. 76-79. ill.

ILYÉs Hajnalka: Nyomdák és könyvek Kolozsvár 18. századában = Erdélyi Múzeum (75.) 2013. 1. 27-33. ill.

\section{0. század}

Persovits József: Magyar betüművészek. Utazás az ólombetük világából a digitalizáció felé = Lupe 2013. 52. 24-25. ill. 


\section{Könyvmüvészet, illusztráció, ex libris}

BoreczKy Anna: Egy avignoni kézirat a középkori Magyarországon, avagy a Ganoysbiblia vándorlásai $=$ Ars Hungarica (39.) 2013. 1. Liber decorum. Wehli Tünde köszöntése 1. 18-27. ill.

Csapody Miklós: Cseh Gusztáv. Kolozsvár: Exit, 2013. 349 p. ill.

FARBAKY Péter: A párizsi Cassianus-corvina és a Corvina könyvtár lombard-ferrarai kapcsolatai = Ars Hungarica (39.) 2013. 1. Liber decorum. Wehli Tünde köszöntése 1. 45-53. ill.

Gellér Katalin: Lakatos Artúr a grafikus és könyvillusztrátor $=$ Egy müvész-polihisztor odüsszeiája a múlt század elején: Lakatos Artúr (1880-1968) / rend. és a katalógust szerk. VÁRKONYI György. Pécs: JPM, 2013. 31-35. ill.

GrÉCZI Emőke: Két vidám könyvművész: Falus Elek és Pólya Tibor = Artmagazin (11.) 2013. 5. 54-57. ill.

Hegedüs András: A Magyar Királyság és uralkodóházainak címerei a Képes Krónika ábrázolásain = Ars Hungarica (39.) 2013. 1. Liber decorum. Wehli Tünde köszöntése 1 . 83-90. ill.

JÉKELY Zsombor: Euraliusnak és Lucretiának szép históriája. Zsigmond császár ábrázolása Aeneas Sylvius Piccolomini szerelmi történetében = Ars Hungarica (39.) 2013. 1. Liber decorum. Wehli Tünde köszöntése 1. 92-99. ill.

Mikó Árpád: Fáncsi Imre armálisa (1511) és két Budán illuminált, kottás díszkódex $=$ Ars Hungarica (39.) 2013. 2. Liber decorum. Wehli Tünde köszöntése 2. 163-173. ill.

MolnÁR-Kovács Zsófia: A tankönyvi illusztráció-kutatás historiográfiája = Iskola a társadalmi térben és időben 2011/2012. [2013.] 147-155.

A 2011/2012 tárgyévvel megjelent kiadvány 2 . kötetében.

Persovits József: Magyar betümúvészek. Az ólombetűtől a digitális világig. Bp.: Optima Téka, 2013. 134 p. ill. (Nyomdász könyvtár)

RADEK Tünde: Középkori történetírás és képi ábrázolás. Johannes de Utino „Világkrónikájának" német nyelvű kéziratai, 15. század =
Ars Hungarica (39.) 2013. 2. Liber decorum. Wehli Tünde köszöntése 2. 175-187. ill.

Soós Imre: Fery Antal grafikusművész élete és munkássága $=$ Zempléni Múzsa (13.) 2013. 2. 46-58. ill.

StudničKovÁ, Milada: Calendarium Pragense Cod. lat. 555 der Széchényi-Nationalbibliothek in Budapest = Ars Hungarica (39.) 2013. 2. Liber decorum. Wehli Tünde köszöntése 2. 195-201. ill.

SZILÁGYI András: Illusztrált díszcímlapok Pázmány Péter Kalauz című müvéhez és Káldi György bibliafordításához = Pázmány nyomában. Tanulmányok Hargittay Emil tiszteletére / szerk. AJKAY Alinka, BAJÁKI Rita. Vác: Mondat, 2013. 395-407. ill.

TATAY, Anca Elisabeta: On the history and art of the old Romanian books. The engravings of Buda, 1780-1830 = MKsz (129.) 2013. 1. 58-69. ill.

TÖRÖK Gyöngyi: Matthias Borhy minister provincialis miniatúra-portréja 1595-böl = Nyolcszáz esztendős a ferences rend... 2. köt. 831-839.

VASNÉ Tóтн Kornélia: A magyar ex libris-szakirodalom óriása, Galambos Ferenc $=\operatorname{KKK}(22$.) 2013. 12. 46-49.

Megjelent még: Kisgrafika (52.) 2013. 4. 4-6. ill.

WeHLI Tünde: Újabb kutatások az Assisi-beli magyarországi ferences kódex iniciáléi körül = Nyolcszáz esztendős a ferences rend. . . 2. köt. 772-782.

\section{Kisnyomtatványok}

Balogh András, F.: „Hogy legyen töröknek ellenállni képes". A 16. század elejének magyar vonatkozású német röpiratai $=$ Nyelv, lelkiség és regionalitás... 516-532.

EtÉNYI Nóra, G.: Politikai és publicisztikai kontextus. Bethlen Gábor a Német-római Birodalomban kiadott nyomtatványokban, 1619-1622 = Bethlen Gábor és Európa / szerk. KÁRmÁn Gábor, Kees Teszelszky. Bp.: ELTE BTK Középkori és Kora Újkori M. Történeti Tansz.-Transylvania Emlékeiért Tud. Egyes., 2013. 245-274. ill. 
KÁDÁr Zsófia: Két ismeretlen társulati kisnyomtatvány a Jézus Társasága Magyarországi Rendtartományának Levéltárából. Pótlás az RMNyhez $=$ MKsz (129.) 2013. 3. 372-380. ill.

KATONA Anikó: A dicsőséges magyar plakát. 1. Bottlik József = Artmagazin (11.) 2013. 4. 38-45. ill.

Katona Anikó: Filmek, revük, sztárok. RézDiamant Tibor és a '20-30-as évek filmplakátjai = Artmagazin (11.) 2013. 5. 42-47. ill.

Katona Anikó: Ungarische Plakate des Ersten Weltkriegs. Ikonografie der Propaganda im internationalen Kontext $=$ Hungary in context. Studies on art and architecture / ed. by Anna Tüskés, Áron TóTH, Miklós SzÉKELY. Bp.: CentrArt, 2013. 211-224. ill.

Kecskeméti Gábor: A magyarországi szlovakizáló cseh nyelvü halotti beszédek kutatásának helyzete $=$ Docendo discimus. Doktoranduszhallgatók és témavezetőik közös tanulmányai a Miskolci Egyetem Irodalomtudományi Doktori Iskolájából / szerk. Huszti Tímea. Miskolc: ME Irodalomtud. Doktori Isk., 2013. 7-14.

KNAPP Éva: „Wirtusfü Wirágból kötöm Wers Rósáit”. Egy ismeretlen Berei Farkas András-nyomtatvány 1820-ból = Doromb 2012. 1 . 195-202. ill.

KovÁcs Eszter: Charintus, a gyermeki szeretet példája. Nagyszombatban nyomtatott iskoladráma-program az Uherské Hradiště-i jezsuita kollégium számára $=$ Szín, játék, költészet... 270-275.

MURÁNYI Gábor: Kiragasztott fordulatok. Nyolc és fél évtized könyvheti plakátjai $=\operatorname{Hvg}(35$.) 2013. 22. 49-51. ill.

Soós Sándor: Szent Emid (Emőd, Emigdius, Emygdius) tiszteletéhez. Egy 1764-es rézmetszetes imalap és Faludi Ferenc S. J. költeménye = Magyar Sion (7.) 2013. 1. 149-155. ill.

\section{Térképészet}

Borsos Balázs: A kérdőívtől a klaszteranalízisig. A második olvasat = Ethnographia (124.) 2013. 3. 364-376.

Az európai néprajzi atlaszok listájával

FILEP Antal: A történeti Magyarország etnikus viszonyainak térképi bemutatása az 1910. évi népszámlálás alapján $=$ A KSH Könyvtár 1945 előtti magyar és magyar vonatkozású térképei / szerk. Nemes Erzsébet; a katalógust összeáll. KovÁcs Zsuzsa, LelKes György, Retтich Béla. Bp.: KSH Kvt., 2013. 35-59. ill.

Holló Szilvia Andrea: Klösz György és a térképnyomtatás $=$ Budapest (34.) 2013. 8 . 20-22. ill.

IRÁs Krisztina: A Magyar Királyság első térképi megjelenése 14. századi portolán térképeken = Földrajzi Közl. (137.) 2013. 1. 64-73. ill.

JANKó Annamária: A Mária Terézia Katonai Rend és az első katonai felmérés $=$ Peremirat. Köszöntő írások Makai Ágnes 70. születésnapjára. Bp.: HM Hadtörténeti Intézet és Múzeum, 2013. 87-94. ill.

JENEY János: Magyar vonatkozású néprajzi térképek Németországban $=$ GeodKart $(65$.) 2013. 11/12. 22-25. ill.

KLINGHAmmer István: Kétszáz éve született Tóth Ágoston honvédezredes, az MTA tagja, a 19. századi magyar térképezés úttöröje = GeodKart (65.) 2013. 1/2. 9-12.

KovÁCs Zsuzsa - LelKes György: A KSH Könyvtár 1945 előtti magyar és magyar vonatkozású térképei = Tud. Müsz. Táj. (60.) 2013. 10. 423-428. ill.

A KSH Könyvtár 1945 elötti magyar és magyar vonatkozású térképei / szerk. NemEs Erzsébet; a katalógust összeáll. KovÁcs Zsuzsa, Lelkes György, Rettich Béla. Bp.: KSH Kvt., 2013. 430 p. ill.

LELKES György: A KSH Könyvtár 1945 előtti térképeinek, illetve elektronikus térképészeti dokumentumainak felhasználása a Magyarország történeti helységnévtára (1773-1808) címủ sorozat köteteinél $=$ A KSH Könyvtár 
1945 elötti magyar és magyar vonatkozású térképei. Bp.: KSH Kvt., 2013. 61-74. ill.

Lovizer Lilla: A prágai Felkl cég glóbuszai a 19. századi magyar földrajzoktatásban $=$ GeodKart (65.) 2013. 3/4. 18-21. ill.

MıkLós Réka: Háromszék története térképeken. Sepsiszentgyörgy: Háromszék Várm. K., 2012. 67 p. ill.

PAPP-VÁry Árpád: Egy „elfeledett geográfus” el nem felejtett térképészeti munkájáról = Földrajzi Közl. (137.) 2013. 1. 78-80.

Fodor Ferenc (1887-1962)

PAPP-VÁRY Árpád: Ernst Schotte magyar nyelvü földgömbjei és dombortérképei $=$ GeodKart (65.) 2013. 9/10. 9-11. ill.

Petelei Klára: Descriptio Transylvaniae. Sepsiszentgyörgy: Székely Nemz. Múz.-Art Printer, 2013. 191 p. ill.

Plihál Katalin: Az Országos Magyar királyi Statisztikai Hivatal térképészete és térképei a nemzetközi földrajzi világkiállítások tükrében = A KSH Könyvtár 1945 előtti magyar és magyar vonatkozású térképei. Bp.: KSH Kvt., 2013. 23-34. ill.

PLıHÁl Katalin: A Tabula Hungariae... Ingolstadt, 1528. Térkép és utóélete az eddigi és a jelenlegi kutatások tükrében. Bp.: OSZKKossuth, 2013. 224 p. ill. + DVD-ROM

TAMÁs Sándor: Erdély „hibás” miniatür térképe Abraham Ortelius atlaszában $=$ Acta Siculica 2013. 477-482. ill.

\section{Papír}

BAlogh Ákos Csaba: Fél évszázada jelent meg Bogdán István ipartörténeti könyve, 19632013 = MVízjel (11.) 2013. 25. 29-31. ill. Bogdán István: A magyarországi papíripar története: $1530-1900$

Pelbárt Jenő: Adatok Teplic papírmalom vízjelhasználatához = MVízjel (11.) 2013. 22. 13-18.

Pelbárt Jenő: Az Aranygyapjas Rend jelvénye és a Szent István-rend nagykeresztje Wenko Ostwald lékai vízjelében = MVízjel (11.) 2013. 25. 15-18. ill.
Pelbárt Jenő: Bárka-vízjelek, a teplici motívumvilág ritkaságai, 1726-1733 = MVízjel (11.) 2013. 22. 43-44. ill.

Pelbárt Jenő: Brassó papírmalom újabb Coronae-vízjele, $1788=$ MVízjel (11.) 2013. 23. 16. ill.

Pelbárt Jenő: Dáma-vízjel, Teplic papírmalom egyik ritka nőalakja, 1740-1748 = MVízjel (11.) 2013. 22. 49-50. ill.

Pelbárt Jenő: Daniel Schultz lőcsei nyomdász működésének teplici és egyéb vízjelei, 1617-1622 = MVízjel (11.) 2013. 23. 5-10. ill.

PelBÁRT Jenő: Dejte papírmalom csillagos horgony-vízjele = MVízjel (11.) 2013. 24. 2324. ill.

Pelbárt Jenő: Egy német nyelvű Schedel-kódex vízjeleiről = MVízjel (11.) 2013. 24. 37-41. ill.

Pelbárt Jenő: Egy érdekes stílusú és ritka erdélyi papírmalomnév-vízjel margójára = MVízjel (11.) 2013. 25. 23-24. ill.

PelbÁRT Jenő: Heraldikai eredetű motívumok és motívum-elemek a filigranológiában = MVízjel (11.) 2013. 25. 3-14. ill.

PelbárT Jenő: A lőcsei Klöss-nyomda kiadványának teplici vízjelei, 1614 = MVízjel (11.) 2013. 23. 3-4. ill.

PelbárT Jenő: Négyszázalékjel a teplici vízjelekben = MVízjel (11.) 2013. 24. 25-36. ill.

Pelbárt Jenő: Ráday Pál Mercurius Veridicus kéziratának vízjele, 1706 = MVízjel (11.) 2013. 25. 19-22. ill.

PelbÁRT Jenő: A Schönsperger-féle Schedel-világkrónikák vízjeleiről, 1496-1500 = MVízjel (11.) 2013. 25. 25-28. ill.

Pelbárt Jenő: Teplic papírmalom címer-vízjelei = MVízjel (11.) 2013. 22. 19-32. ill.

PelbáRT Jenő: Teplic papírmalom IHS-vízjel változatai, 1692-1756 = MVízjel (11.) 2013. 22. 45-48. ill.

PelBáRT Jenő: Teplic papírmalom postakürt-vízjelei = MVízjel (11.) 2013. 22. 33-42. ill.

PelbárT Jenő: Teplic papírmalom rizsmajegye 1827-ből = MVízjel (11.) 2013.22. 11-12. ill.

Pelbárt Jenő: Teplic papírmalom vízjelei az Animadversiones apologicae Ráday röpirat papírjában, 1706 = MVízjel (11.) 2013. 23. 29-30. ill. 
PeLBÁRT Jenő: Teplic papírmalom vízjelvilága. Az előszót írta Diószegi György Antal. Bp.: M. Papír- és Vízjeltörténeti Társ., 2013. 276 p. ill. Pelbárt Jenő: Teplici és egyéb vízjelek a lőcsei Brewer-nyomda kiadványaiban az 1626-1708 közötti időszakban = MVízjel (11.) 2013. 23. 11-15. ill.

Pelbárt Jenő: Teplici vízjelek Geleji Katona István Váltság titka címủ könyvének papírjában, 1645 = MVízjel (11.) 2013. 23. 17-18. ill.

Pelbárt Jenő: Wendelin Keresztényi Isteni Tudósítások címü könyvének vízjelei, $1674=$ MVízjel (11.) 2013. 23. 19-24. ill.

Rо́тн András Lajos: A színes papír történetéböl [1-5.] = Örökségünk 1. rész: (5.) 2011. 4. 12-14. ill.; 2. rész: A nyomómintás papír (6.) 2012. 2. 26-28. ill.; 3. rész: A bronzfirnisz és a brokátpapír (6.) 2012. 3. 12-14. ill.; 4. rész: A márványpapírok (6.) 2012. 4. 22-24. ill.; 5. rész: A könyvmetszések színezése (7.) 2013. 1. 10-12. ill.

\section{Könyvkötés-történet}

FA Lili Eszter: Egy genfi antikva restaurálása a Pápai Református Gyüjtemények könyvtárából [1-2.] = Acta Papensia (13.) 2013. 1. közl.: 1. 4-18. ill.; 2. közl.: 2. 153-174. ill.

\section{Könyvkereskedelem, -terjesztés}

GrANASZTói Olga: Adalékok a francia könyv európai terjesztési hálózatainak feltáráshoz. 2. A Société Typographique de Neuchâtel bécsi kapcsolatai 1785-1789 = MKsz (129.) 2013. 2. 165-177.

Simon Melinda: Az Aufrecht és Goldschmied könyvterjesztő vállalkozás története és jelvényhasználata = MKsz (129.) 2013. 2. 219-231. ill.

\section{Kiadástörténet}

\section{Több évszázadot érintő munkák}

BÁN Izabella: Gondolatok az általános és a társulati imakönyvek kapcsolatáról $=$ Studia Litteraria (52.) 2013. 3/4. 371-377.

KovÁcs Bálint: Örmény könyvkultúra és örmény irodalmi értékek a Kárpát-medencében $=$ Távol az Araráttól. Örmény kultúra a Kárpát-medencében. A Budapesti Történeti Múzeum és az Országos Széchényi Könyvtár közös kiállítása. 2013. április 5-2013. szeptember 15. / rend., kat. szerk. Kovács Bálint, PÁl Emese. Bp.: BTM-OSZK, 2013. 53-63. ill.

MonOK István: Le livre parisien en Hongrie et en Europe centrale, $\mathrm{XV}^{\mathrm{e}}-\mathrm{XVII}{ }^{\mathrm{e}}$ siècles $=$ Histoire et civilisation du livre (8.) 2012. 251-267.

NÉMETH Dávid: Protestáns gyermekbibliák a reformációtól napjainkig = Collegium Doctorum (9.) 2013. 85-101. ill.

Sill Aba Ferenc: Corvina a Ferences rend gyüjteményében $=$ Vasi Honism. és Helytört. Közl. 2012. 2. 12-16. ill.

SzABó Zoltán Ádám: A magyar képregény és az önkifejezés = Szépirod. Figy. 2013. 4. Képregény. 35-45.

\section{5. század}

FARKAS Gábor Farkas: A Budai Krónika Princetonban = Iskolakultúra (23.) 2013. 2. 91-95.

FARKAS Gábor Farkas: A budai krónika rejtélyei [1-3.] = MG (57.) 2013. 1. rész: 3. 75-79. ill.; 2. rész: 4. 76-79. ill.; 3. rész: 6. 74-79. ill. Mátyus Norbert: A Missale Dominorum Ultramontanorum keletkezéstörténetéhez $=\mathrm{MKsz}$ (129.) 2013. 3. 357-361.

\section{5-16. század}

MonoK István: Város és könyvkultúra Magyarországon a XV. század végén és a XVI. században. A könyvkiadási adatok tanulságai $=$ Pro nonagesimo. Tanulmányok Schultheisz Emil professzor 90. születésnapjára / szerk. 
Kapronczay Károly, Kapronczay Katalin. Bp.: Semmelweis, 2013. 145-158.

\section{6. század}

Ács Pál: A látható nyelv. A költészet vizuális képe a XVI. századi magyar könyvekben $=$ Doromb 2012. 1. 42-58. ill.

Almási Gábor-Kiss Farkas Gábor: Szöveggondozás és kapcsolatápolás. Zsámboky János életmüve a reneszánsz filológia tükrében = ItK (117.) 2013. 6. 627-691.

BARTók István: „Poëtica est...”. Johann Honter latin grammatikájának irodalomelméleti vonatkozásai = ItK (117.) 2013. 2. 123-141. A mű kiadástörténetéről, filológiájáról

SzoLIVA Gábriel: Előkerült Oláh Miklós esztergomi érsek kottás Psalterium Strigoniense-je (1523) Münchenböl [1-2.] = MEgyházzene (20.) 2012/2013. 1. rész: Az új forrás leírása és antifónáinak elemzése 1 . 55-66. ill.; 2. rész: A himnárium jellemzése 2. 121-156. ill.

SzoLIVA Gábriel: Újabb liturgikus könyv Oláh Miklós esztergomi érsek könyvtárából. Kottás Psalterium Strigoniense (1523) került elő Münchenből = MKsz (129.) 2013. 2. 133-144. ill.

Ubrizsy SAVoIA Andrea: Tulajdonosi bejegyzések és magyar növénynevek Petro Pena és Matthias Lobelius Stirpium Adversaria Nova (1570) címủ könyvének egy példányában = Savaria (36.) 2013. 17-21. ill.

\section{6-17. század}

DomBI Anikó: Szent Vilma magyar királyné legendájának és misztériumjátékának 16-17. századi nyomtatott forrásai az Országos Széchényi Könyvtárban = MKsz (129.) 2013. 1 . 47-57. ill.

GÁBOR Csilla: Trient után. Bibliafordítás, bibliafilológia, lelkiségi hagyományok. Gondolatok Hargittay Emil előadása kapcsán = Fejezetek a kora modern esztétikai gondolkodás történetéböl, 1450-1650. Tanulmányok / szerk. HorkaY Hörcher Ferenc; a szöveget és a jegyzeteket gond. Híz Ágnes. Bp.: L'Harmattan, 2013. 173-183.

HARGITTAY Emil: A trienti határozatok hatása a magyarországi irodalomra $=$ Fejezetek a kora modern esztétikai gondolkodás történetéből, 1450-1650. Tanulmányok / szerk. HoRKAY Hörcher Ferenc; szöv. és jegyz. gond. Híz Ágnes. Bp.: L'Harmattan, 2013. 86-100. ill.

\section{7. század}

EMŐDI András: Az 1686-ban megtalált budai királyi kápolna-könyvtár újabb darabja (hajdan a váradi egyházmegye eddig ismeretlen vikáriusának tulajdonában) = MKsz (129.) 2013. 2. 235-237. ill.

Hargittay Emil: „...az ártatlanság még az ellenséget is gyakorta kegyességre indittya". Még egyszer a Káldi Biblia támogatásáról = ItK (117.) 2013. 1. Bethlen Gábor - irodalom, vallás, tudományosság. 82-87.

Hevesi Andrea: RMNy 1615. Egy unitárius imaénekeskönyv töredéke, a többi 17 . századi unitárius énekeskönyv tükrében $=$ Keresztény Magvető (119.) 2013. 4. 377-390.

Pesti Brigitta: Dedikáció és mecenatúra Magyarországon a 17. század első felében. Bp.: Kossuth; Eger: EKF, 2013. 493 p. ill. (Kulturális örökség)

Pesti Brigitta: „Az igaz apostoli vallás bőkezű gyámoli”. A magyar nyelvü kegyességi irodalom mecenatúrája a 17. század első felében = Studia Litteraria (52.) 2013. 3/4. 318-340.

Pesti Brigitta: Irodalmi mecenatúra Magyarországon a 17. század első felében $=$ Nyelv, lelkiség és regionalitás... 544-566. ill.

ThimÁr Attila: „A méret a lényeg”. Gondolatok a Kalauz könyvformájáról = Pázmány nyomában. Tanulmányok Hargittay Emil tiszteletére / szerk. AJKAY Alinka, BAJÁKi Rita. Vác: Mondat, 2013. 435-440.

\section{7-18. század}

KÁDÁr Zsófia: A pozsonyi jezsuita kollégium Mária-társulatának könyvkiadása és könyvterjesztése = Egyháztört. Szle (14.) 2013. 1 . 5-45. ill. 
18. század

Debreczeni Attila: Kazinczy ismeretlen félíves nyomtatványa a kassai Magyar Museum indulása előtti évből = Széphalom (23.) 2013. 267-275.

FeKeTE Csaba: Ortodoxa Eklésiáknak tetszésekből... Helyesbítések és adalékok a II. Helvét Hitvallás hazai kiadásához $=$ MKsz (129.) 2013. 3. 306-321. ill.

Hegri Ádám: „Mit mondasz mindezekre te vallást csúfoló!’' Id. Ercsei Dániel (1744-1809) és a hitvédő irodalom = Egyháztört. Szle (14.) 2013. 3. 22-25.

IvANCSó Mária: „Kicsoda az ember a' ki él, és a halált nem láttya". 18. századi katolikus halotti prédikációk egy kolligátumban $=\mathrm{Ju}$ venilia 2013. 156-167. ill.

JuHÁsz Zoltán: A barokk felsőoktatás új könyvmüfaja: a liber gradualis. Közrem. SURÁNYI Imre. Eger: Magánkiad., 2013. 49 p. ill.

JuHÁsz Zoltán: Disputáció és liber gradualis. Müfajok és módszerek = Palócföld (59.) 2013. 4. 63-73. ill.

KnAPP Éva: „Ex mellifluis verbis”. Martin von Cochem (Linius, 1634-1712) imádságoskönyve magyarul, 1681 = Studia Litteraria (52.) 2013. 3/4. 341-362.

KNAPP Éva: Spangár András és a Magyarok bibliotékája. Fejezet a 18. századi historia litteraria történetéből $=$ ItK (117.) 2013. 3. 247-280.

Szuly Rita: Hit, nem hit. „A ki hiszen a Kristusban és nem hiszen a Kristusnak, nincs igaz hite". A győri Jó halál társulat kiadvány-finanszírozó tevékenysége a 18. század derekán= Szín, játék, költészet... 85-93.

18-19. század

CsöRsz RuMEN István: Az első magyar lírai antológia: a váci Énekes Gyüjtemény (1799, 1801, 1803, 1823) = Doromb 2012. 1. 141-178. ill.

SzILI Katalin: Bél Mátyás Sprachmeistere újra és újra = MNyelv (108.) 2012.3.341-357. ill.
19. század

BÉNYEI Miklós: „Könyvhöz hasonló az ember...”. Eötvös József és a magyar könyvkiadás = KKK (22.) 2013. 8. 50-57.

\section{9-20. század}

Komoróczy Szonja Ráhel: Héber nyomdák, könyvkultúra $=$ Zsidók Kárpátalján. Történelem és örökség a dualizmus korától napjainkig / szerk. BÁNYAI Viktória, FedineC Csilla, Komoróczy Szonja Ráhel; a térképeket kész. NAGY Béla. Bp.: Aposztróf, 2013. 85-94. ill.

\section{0. század}

JóNÁs Károly: Az Országgyülési Könyvtár „első”, kiadatlan évkönyvének története $=\mathrm{KF}$ (23.) 2013. 3. 521-531.

KERESZTY Orsolya: Egy úttörő vállalkozás a századfordulón. A „Modern Ifjúsági Könyvtár” születése = MKsz (129.) 2013. 1. 108-112.

Lipócziné Csabai Sarolta: Könyvkiadás és múfordítás kultúrpolitikai kontextusban. Adalékok a német irodalom magyarországi recepciójához $=$ Agtedu 2012. A Magyar Tudomány Ünnepe alkalmából rendezett 13. tudományos konferencia... Kecskemét, 2012. november 13. Kecskemét: Kecskeméti Főisk. Tanítóképző Főisk. Kar, 2012. 114-119.

Scheibner Tamás: Könyvkiadás a koalíciós években. A Szikra Nyomdai, Irodalmi és Lapkiadó Vállalat és a politikai fordulat $=$ MKsz (129.) 2013. 4. 456-476.

\section{Sajtótörténet}

\section{Több évszázadot érintő munkák}

ANDoK Mónika: A hírek története. Bp.: L’Harmattan, 2013. 261 p. ill. Sajtótörténeti vonatkozásokkal

Emlékkönyv a Szemészet címü folyóirat alapításának 150. évfordulójára / szerk. NÉMETH 
János, NAGY Zoltán Zsolt. Bp.: M. Szemorvostárs., 2013. 136 p. ill.

KÁldos János: Az elmúlt 150 év és a digitális jövő = Keresztény Magvető (118.) 2012. 2. 127-135.

Kо́тYUK Erzsébet: Adalékok a Szemészet folyóirat százötven éves történetéhez, 1864-2013 = Orvosi Hetilap (154.) 2013. 52. 2078-2085.

KóтYUк Erzsébet: Másfél évszázad. A Szemészet címü folyóirat története = Emlékkönyv a Szemészet című folyóirat alapításának 150 . évfordulójára / szerk. NÉMETH János és NAGY Zoltán Zsolt. Bp.: M. Szemorvostárs., 2013. 3-23.

PINTÉR Györgyi: Sajtókutatás - divatlapkutatás. A reformkori divatlaptörténet-írás esélyei $=$ Médiakutató (14.) 2013. 4. 37-44.

\section{8-19. század}

DöRNYEI Sándor: Elvetélt folyóirat-tervek az Orvosi Hetilap megindulásáig = Orvosi Hetilap (154.) 2013. 24. 74-75.

\section{9. század}

BALogh János Mátyás: A Lloyd-mechanizmus. Krízis és árpolitika a lapkiadásban, 1860-as és 1870-es évek = Korall (14.) 2013. 54. Válság/történetek. 43-62. ill.

DEÁK Ágnes: „A politika ne nyulj hozzám-virág volt”. Sajtószabályozás a Schmerling-provizórium időszakában = Századok (147.) 2013. 3. 625-653.

DöRNYEI Sándor: A meginduló Orvosi Hetilap fogadtatása $=$ Orvosi Hetilap (154.) 2013. 2 . 74-75.

PÉTER Edit: Mit írok? Miért írok? Hogyan írok? Kérdésfelvetések egy 19. századi sajtótörténeti kutatás kapcsán $=$ „Kit érdekel az irodalom-rizsa?" (Esti) és mire jó egyáltalán? A BBTE Magyar Irodalomtudományi Intézet 2011. évi házikonferenciája / szerk. BerszÁn István, Selyem Zsuzsa. Kolozsvár: Egyetemi Műhely K.-Bolyai Társ., 2012. 87-96.

PINTÉR Györgyi: Az első írói sztrájk sajtótörténeti vonatkozásai $=$ Tavaszi Szél, 2013. Konferenciakötet / szerk. KERESZTES Gábor.
Bp.: Doktoranduszok Orsz. Szöv., 2013. 2. köt. 293-298.

Rózsa Mária: Magyar és német irodalmi kapcsolatok a Pester Sonntagsblattban, 18531855. [1-2.] = MKsz (129.) 2013. 1. rész: 1. 70-76.; 2. rész: 2. 178-195.

Rózsa Mária: Pesti német nyelvű lapok a kultúraközvetítés szolgálatában a reformkorban és az 1850-es években. Bp.: Argumentum, 2013. 304 p. ill. (Irodalomtörténeti füzetek; 173.)

SzALISZNYó Lilla: Ami szegény Hamlettől telnék. A hivatásos színészi identitás problematikája Egressy Gábor Magyar Színházi Lapjában = It (94.) 2013. 1. 53-76.

TAMÁs Ágnes: Nemzetiségi sztereotípiák és a humor eszközei a 19. század második felében = Sokszínü humor. A III. Magyar Interdiszciplináris Humorkonferencia előadásai / szerk. VArgha Katalin, T. Litovkina Anna, BARTA Zsuzsanna. Bp.: Tinta Kvk.-ELTE BTK-M. Szemiotikai Társ., 2013. 121-130. ill.

\section{9-20. század}

BordÉ Katalin: A Nyírvidék hetilapból napilappá alakulása, 1880-tól 1918-ig = Szabolcs-Szatmár-Beregi Szle (48.) 2013. 3. 39-48. ill.

KLestenitz Tibor: Gerely József karrierje. Falak és választóvonalak a katolikus nagygyülések ,szürke eminenciásának” életében = Egyháztört. Szle (14.) 2013. 3. 67-82.

KLESTENITZ Tibor: A katolikus sajtómozgalom Magyarországon, 1896-1932. Bp.: Complex, 2013. 314, XLII p. ill.

KövÉR György: A Magyar Gazdaságtörténelmi Szemle (1894-1906) gazdaságtörténete. Intézményi megközelítés és historiográfia = Történelmi Szle (55.) 2013. 2. 201-224. ill.

MÁk Ferenc: Brájjer Lajos és a mértéktartó Fiumei Estilap = Hungarológiai Közl. (44. = Ú.f., 14.) 2013. 3. 111-119.

20. század

AgÁRDI Péter: Pándi Pál Kritikája és a Kritika Pándija = Kritika (42.) 2013. 11/12. 4-8. 
Albertini Béla: A magyar sajtó fényképei és a nagyvilág - a két világháború között $=$ Nyitott - zárt Magyarország. Politikai és kulturális orientáció, 1914-1949 / szerk. FeITL István. Bp.: Napvilág, 2013. 196-212.

BoDó Márta: Jóbarát. Egy erdélyi katolikus ifjúsági lap a két világháború között. Kolozsvár: Verbum, 2013. 228 p.

Czeferner Dóra: Két feminista folyóirat az Osztrák-Magyar Monarchiában $=11$. Országos Interdiszciplináris Grastyán Konferencia előadásai / szerk. Szamonek Vera. Pécs: PTE Grastyán E. Szakkollégium, 2013. 58-65.

DÁvID Gyula: Az Erdélyi Helikon a negyvenes években $=$ Korunk (23.) 2012. 12. Popkritika. 86-93.

Megjelent még: Forrás (45.) 2013. 1. 61-69.

DEMETER Zsuzsanna: Vicclapok világképe, 19451950 = Nyitott - zárt Magyarország. Politikai és kulturális orientáció, 1914-1949 / szerk. Feitl István. Bp.: Napvilág, 2013. 340-353. ill.

FILeP Tamás Gusztáv: Bölcselők, szellemtörténészek, esszéírók a Napkeletben = Tormay Cécile-emlékkonferencia: 2012. október 5. Bp.: MMA, 2013. 105-117.

Galambos Sándor: A Szabolcsi Szemle első évtizede, 1934-1944 = Szabolcs-SzatmárBeregi Szle (48.) 2013. 3. 49-54. ill.

HoRvÁth Attila: A magyar sajtó története a szovjet típusú diktatúra idején. Bp.: Médiatud. Int., 2013. 95 p. (Médiatudományi könyvtár; 7.)

IgNÁCZ Ádám: A populáris zene megítélésének változásai a kádári Magyarország ifjúsági sajtójában. Az első 15 év, 1957-1972 = Médiakutató (14.) 2013. 4. 7-17.

KALMÁR Melinda: A kritikai gondolkodás integrálása a szovjet rendszerbe $=$ Kritika (42.) 2013. 11/12. 9-11.

Katona Anikó: A háború képe. A hadifestők és a Sajtóhadiszállás viszonya az első világháborúban - a bécsi Állami Levéltár iratai alapján = Esemény és narratíva... 270-287. ill.

KereKes Amália - Teller Katalin: Aki másnak vermet ás... A bécsi és a budapesti lapok rejtvényrovata 1916-ban $=$ Sic Itur Ad Astra 2013. 63. Csak játék? 167-177.
KóKAI Károly: The aesthetics of the periodical Magyar Mühely $=$ Hungarian Studies (27.) 2013. 1. 95-106.

Kollarits Krisztina: Tormay Cécile és a pályakezdő írók. A Napkelet megújulása az 1930-as években $=$ Tormay Cécile-emlékkonferencia: 2012. október 5. Bp.: MMA, 2013. 81-104.

Komoróczy Szonja Ráhel: Kárpátaljai zsidó saj-tó = Zsidók Kárpátalján. Történelem és örökség a dualizmus korától napjainkig / szerk. Bányai Viktória, Fedinec Csilla, KomoRÓczY Szonja Ráhel; a térképeket kész. NAGY Béla. Bp.: Aposztróf, 2013. 196-206. ill.

Komoróczy Szonja Ráhel: A munkácsi jiddis sajtó a két világháború között = Önazonosság és tagoltság. Elemzések a kulturális megosztottságról. Évkönyv, 2011-2012 / szerk. BÁRdi Nándor, Tóth Ágnes. Bp.: Argumentum, 2013. 315-326.

Köszegralvi Ferenc: A hódmezővásárhelyi sajtó megújulása az 1970-es évektől = KKK (22.) 2013. 4. 43-47.

KosztolÁnczy Tibor - NemeskérI Erika: Festő a fronton = Esemény és narratíva... 288304. ill.

Cselényi-Walleshausen Zsigmond Osvát Ernőnek írt levelei közlésével

Kosztolányi Dezső napilapokban és folyóiratokban megjelent írásainak jegyzéke / szerk. Arany Zsuzsanna; kész. az MTA-ELTE Hálózati Kritikai Szövegkiadás Kutatócsoport. Bp.: Ráció, 2008-

5. Határon túli lapok 2. A romániai magyar (bánsági, erdélyi és partiumi) sajtó anyaga 1. Heti- és havilapok / szerk. DoвÁs Kata. 2013. 84 p.

LAKos János: A Levéltári Szemle az 1960-as évek magyar levéltárügyében = Amikor ,fellazult tételben fogalmazódott meg a világ". Magyarország a hatvanas években / szerk. ÓLMOSI Zoltán, Szabó Csaba. Bp.: M. Nemz. Lvt. Orsz. Lvt.-L'Harmattan, 2013. 131-142. ill.

LENGYel András: A Hét ,utolsó” szerkesztőjének portréjához $=$ MKsz (129.) 2013. 2. 238-241.

LENGYel András: Ki írta A Hét Ady-ellenes gloszszáját? = MKsz (129.) 2013. 1. 106-107. 
Lengyel András: A mindennapok szemüvegkészítői. Sajtótörténeti tanulmányok. Bp.: Nap K., 2013. 383 p. ill. (Magyar esszék)

LENGYel András: A Nyugat „iskolájának” elvetélt terve, $1918=$ MKsz (129.) 2013. 4. 489-493.

LENGYel András: A Nyugat munkatársi gárdájának összetétele, 1908-1910 = MKsz (129.) 2013. 2. 196-218.

Lengyel András: Sebestyén Arnold és Az Est médiamarketingje 1919-1930 = A mindennapok szemüvegkészítői. Sajtótörténeti tanulmányok / LengYel András. Bp.: Nap K., 2013. 256-320.

MÁk Ferenc: A továbbélni-tudás forrásvidékén. Magyar sajtó a Délvidéken 1914-1944 = Magyar sajtószabadság... 33-54.

NÁDOR Orsolya: A Magyarságtudomány címü folyóirat szerepe a hungarológia fogalmának alakulásában = Hungarológiai Évk. (14.) 2013. 1. 195-208.

NAGY Gábor: A Magyar Nemzet ügye 1945 tavaszán. Barankovics István a koalíciós sajtópolitikáról [elektronikus dok.] = ArchivNet (13.) 2013. 5.

Elektr. hely és hozzáférés: http://www.archivnet.hu/politika/a_magyar_nemzet_ugye_ 1945 tavaszan.html

NAGY Gábor, Sz.: Nagy Ferenc és Rajk László sajtórendészeti vitája 1946-ban. Adalékok Rajk László belügyminiszteri működéséhez = In Medias Res (2.) 2013. 2. 247-260.

NÉMETH Luca Anna: Zsidó figurák nevei a Borsszem Jankóban a 20. század első felében = Névtani Értesítő (34.) 2012. 49-65.

NÉMETH Vera: Az Egyenlőség küzdelme a zsidó nemzeti mozgalom ellen $=$ Hallgatói mühelytanulmányok (DE, BTK. Történelmi Intézet). 2013. 2. 243-261.

ORBÁN István: Jóbarát, 1925-1940. Egy katolikus ifjúsági folyóirat képanyaga = Művelődés (66.) 2013. 4. 11-15. ill.

Ozsváth Judit: Az Erdélyi Iskola címü nevelésügyi folyóirat helye és szerepe a két világháború közötti erdélyi magyar pedagógiai sajtóban = Iskola a társadalmi térben és időben 2011/2012. [2013.] 153-162.
A 2011/2012 tárgyévvel megjelent kiadvány 2 . kötetében

PÁlfi József: A média fejlődéstörténete egy poszt-trianoni egyháztestben. Egyházi sajtó a Királyhágómelléki Református Egyházkerületben 1920-1942 között = Időn és tereken át. Tanulmányok az egyház életéről és szolgálatáról / szerk. LÉVAI Attila. Szentendre: Tillinger P. Mühelye, 2013. 117-146.

PетнŐ Villő: Énekszó. Folyóirat a zenei nevelés és az Éneklő Ifjúság szolgálatában = Az életreform és reformpedagógia. Recepciós és intézményesülési folyamatok a 20. század első felében / szerk. NÉMETH András, PIRKA Veronika. Bp.: Gondolat, 2013. 134-151.

Petrik Béla: Ilia Mihály és Kiss Ferenc levele mellé = Magyar Szle (22.) 2013. 9/10. 24-36. A Tiszatáj folyóiratról

PINTÉR Lajos: „Gyüjtsd a termést kalangyába”. A Kalangya története, 1932-1944. Subotica: Életjel, 2013. 110 p. (Életjel miniatürök; 55.)

RÁcz Béláné: Szellemi és politikai keresztmetszetek. Ifjúsági lapok a szegedi egyetemen 1922-1944 = Szeged (25.) 2013. 1. 32-35. ill.

RÓBERT Péter: Két háború között. A cionista sajtó története Magyarországon, 1920-1940. Bp.: Mo. Cionista Szövets., 2013. 246 p. ill. (Bethlen téri füzetek)

RóNAY László: A Nyugat a kortársak mérlegén. A Magyar Kultúra és a Vigilia a Nyugatról $=\mathrm{Az}$ írás erkölcse és erkölcstelensége. Esszék, tanulmányok / RóNAY László. Bp.: Nap K., 2012. 7-48.

SÁndor Krisztina: A Keresztény Magvető újraindítása 1971-ben $=$ Keresztény Magvető (119.) 2013. 3. 165-277.

SÁNDOR Krisztina: Politikai vezércikkek a hetvenes évek Keresztény Magvetőiben = Székelyföld (17.) 2013. 9. 140-154.

SÁrKöZI Éva: A Hét „Innen-Onnan” rovata szerzőinek azonosíthatósága $=$ MKsz (129.) 2013. 3. 381-388.

SomogYvÁri Lajos: Az 1960-as évek képes pedagógiai szaksajtója Magyarországon $=$ Educatio (22.) 2013. 3. Tudáselosztás - tudásmonopóliumok. 418-423.

STANDEISKY Éva: Az Alkotás és a nagyvilág. Egy folyóirat, élete és halála $=$ Nyitott - 
zárt Magyarország. Politikai és kulturális orientáció, 1914-1949 / szerk. FeITL István. Bp.: Napvilág, 2013. 311-320.

SÜKÖSD Miklós: A szamizdat mint tiposzféra. Földalatti nyomtatási kultúra és független politikai kommunikáció a volt szocialista országokban = Médiakutató (14.) 2013. 2. 7-26.

Sulyok Bernadett: Kassáktól a multimediális múvészetig. A Magyar Mủhely öt évtizede = Palócföld (59.) 2013. 2. 70-75.

TAKÁCs Róbert: A Kritika és az értelmiségi sajtó a Kádár-korszakban = Kritika (42.) 2013. 11/12. 16-19.

TAKÁCs Róbert: A Népszava „hiányzó” negyven éve = Médiakutató (14.) 2013. 4. 45-59.

TAKÁCs Róbert: Nyitás és új bezárkózás. A koalíciós napisajtó szellemi Nyugatról alkotott képének változása, 1945-1948 = Nyitott zárt Magyarország. Politikai és kulturális orientáció, 1914-1949 / szerk. FeITL István. Bp.: Napvilág, 2013. 321-339. ill.

TAKÁCS Róbert: A „szocialista sajtószabadság” vitái Magyarországon Sztálin halálától Helsinkiig, 1953-1975 = Magyar sajtószabadság... 66-79.

TAKÁCS Róbert: A sztálini modell átalakítása a magyar tömegkommunikációban = Múltunk (58.) 2013. 3. 68-273.

\section{0-21. század}

TiBoRI Tímea: Közösségkutatások eredményeiről - a Kultúra és Közösség hasábjain = Etnikai leporelló Közép-Európából: kiadványsorozatok tükrében. Tanulmányok / szerk. Kupa László. Pécs: Virágmandula, 2013. 121-128.

\section{Sajtótermékek mint forrásanyagok}

CsÁszÁR Ildikó: Egy kínos jegyzék és annak sajtóvisszhangja = Hallgatói mühelytanulmányok (DE BTK. Történelmi Intézet) 2013. 2. 42-55.

DÁcz Enikő: Interetnikus kapcsolatok a XX. század elején három erdélyi újság tükrében $=$ Századvég 2013. 1. Erdély. 101-128.
DöBÖR András: Széchenyi István politikai programja a Jelenkor tükrében $=$ Hallgatói mühelytanulmányok (DE BTK. Történelmi Intézet) 2013. 2. 85-96. ill.

DukKon Ágnes: Miscellanea de rebus turcarum. Frölich Dávid kalendáriumainak török-képe $=$ Az oszmán-magyar kényszerü együttélés és hozadéka / szerk. J. ÚJvÁRY Zsuzsanna. Piliscsaba: PPKE BTK, 2013. 2. köt. 15-32.

Megjelent még: Az oszmán-magyar kényszerü együttélés és hozadéka / szerk. J. ÚJVÁRY Zsuzsanna. PPKE BTK, 2013. 73-90.

ERDŐDY Gábor: Auguste de Gerando hírlapi cikkei a magyarokról a belga sajtóban, 1849 júliusában = Határon innen, határon túl. Tanulmányok Tilcsik György 60. születésnapjára / szerk. BARISKA István, MAYER László. Szombathely: Vas M. Lvt., 2012. 93-96.

FARKAS Daniella: Természettudományos fordulat a magyar hírlapirodalomban. „Koch Róbert” és a tuberkulózis gyógyítása az 1880-1890-es évek magyar lapirodalmában $=$ Filológia és irodalom. Tanulmányok a Pázmány Péter Katolikus Egyetem Irodalomtudományi Doktori Iskolájának Kárpát-medencei irodalmi MA- és PhD-hallgatók számára rendezett Filológia és irodalom címü konferenciáján elhangzott előadásokból / szerk. ToMPA Zsófia. Bp.: PPKE BTK, 2013. 273-289.

GÁBORI KovÁcs József: Ellenzéki párttöredékek közeledése a publicisztika útján 1845-ben = A kincset csak fáradsággal hozhatjuk napvilágra. Tanulmánykötet báró Eötvös József születésének 200. évfordulójára / szerk. GÁNGó Gábor. Bp.: ELTE Eötvös József Coll., 2013. 261-271.

GLÄSSER Norbert - ZIMA András: Kárpátalja a budapesti zsidó sajtóban = Zsidók Kárpátalján. Történelem és örökség a dualizmus korától napjainkig / szerk. BÁNYAI Viktória, Fedinec Csilla, Komoróczy Szonja Ráhel; a térképeket kész. NAGY Béla. Bp.: Aposztróf, 2013. 214-220.

HANNY Erzsébet: Buda visszafoglalása a 17. századi spanyol híradásokban $=$ Tanulmányok Budapest múltjából 2013. 38. 41-56. ill. 
Magyarországi könyvtárakban őrzött spanyol nyelvü dokumentumokról

KLestenitz Tibor: Két nagygyülés Budapesten = Médiakutató (14.) 2013. 1. 53-64.

MAczó Ferenc: Az utolsó királykoronázás és nádorhelyettes választás a politikai élclapok tükrében $=$ Als ich can. Tanulmányok Urbach Zsuzsa 80. születésnapjára / szerk. Gaylhoffer-Kovács Gábor, Székely Miklós. Bp.: CentrArt, 2013. 134-145. ill.

Máté Zsolt: The 1959 American-Soviet exchange exhibitions and their American-Hungarian press reaction $=$ Szemelvények 2 . Válogatás a PTE BTK XXXI. Országos Tudományos Diákköri Konferencián 2013. első helyezést elért hallgatóinak pályaműveiből / szerk. BöHm Gábor, Fedeles Tamás. Pécs: PTE BTK KTDT, 2013. 209-231.

NAGY Janka Teodóra: A jogi néprajzi kutatások és az Ethnographia = Ethnographia (124.) 2013. 3. 297-320.

NAGY Vilmos Márton: A csernovai tragédia sajtója = Történeti Tanulmányok (20.) 2012. 143-154. ill.

NÉMETH Regina: Népmüvészet és népi kultúra nevelési vonatkozásai a Népmívelésben, 1906-1912 = Az életreform és reformpedagógia. Recepciós és intézményesülési folyamatok a 20. század első felében / szerk. NéMETh András, PIRKA Veronika. Bp.: Gondolat, 2013. 266-298.

TAMÁs Ágnes: „Hogyan lehetne Magyarországon a zsidó kérdést a legpraktikusabban megoldani?!" = Felekezeti társadalom - felekezeti műveltség. A Hajnal István Kör Társadalomtörténeti Egyesület 2011. évi, győri konferenciájának kötete / szerk. LUKÁCS Anikó. Bp.: Hajnal I. Kör Társadalomtört. Egyes., 2013. 277-285. ill.

Herkó páter (hírlap)

TAMÁs Ágnes: Válságtörténetek a humor optikáján keresztül. A gazdasági válságok, az éhínség és a kolera a korabeli élclapokban = Korall (14.) 2013. 54. Válság, történetek. 81-103. ill.

TAMÁs Ágnes: Zsidó személynevek és névmagyarosítás a 19. század végi magyar élclapokban = Névtani Értesítő (34.) 2012.41-48.
VÁRAdI Katalin: Bismarck megítélése a Pesti Napló és az Üstökös alapján, 1863-1871 = Hallgatói mühelytanulmányok (DE BTK. Történelmi Intézet) 2013. 2. 331-340. ill.

VARGA Balázs: A győri politikai és közigazgatási elit a koalíciós időszak (1945-1948) helyi sajtója tükrében $=$ Mühely (36.) 2013. 2 . 61-72.

VARSÁNYI Krisztina: Bethlen Gábor királlyá választása a korabeli német nyelvủ nyomtatott sajtómüfajokban = Bethlen Gábor és Európa / szerk. KÁRmÁn Gábor, Kees Teszelszky. Bp.: ELTE BTK Középkori és Kora Újkori M. Történeti Tansz.-Transylvania Emlékeiért Tud. Egyes., 2013. 275-310. ill.

VeszTróczy Zsolt: A magyar politikai élet szlovák karikatúrák tükrében (1876-1900) = Esemény és narratíva... 132-146. ill.

VINCZE Dániel: Rebellisek, elégedetlenek, magyarok. A Thököly-felkelés a London Gazette hasábjain = Századok (147.) 2013. 4. 889-930.

\section{Könyvtártörténet}

\section{Több évszázadot érintő munkák}

Boross Klára: Az Akadémiai Könyvtár 16. századi gyüjteménye = Tud. Müsz. Táj. (60.) 2013. 4. 169-174.

FArKas Gábor Farkas: Az Országos Széchényi Könyvtár Régi Nyomtatványok Tára [elektronikus dok.] = KF (23.) 2013. 1.

Elektr. hely és hozzáférés: http://ki.oszk.hu/ kf/2013/04/az-orszagos-szechenyi-konyvtari-regi-nyomtatvanyok-tara/\#more-7634

FARKAS Gábor Farkas - MiKó Árpád: Régi kövek, régi könyvek. A Budai Krónika Jankovichpéldánya és az Egyetemi Könyvtár régi kőgyüjteménye $=$ MüvtörtÉrt (62.) 2013. 1 . 1-16. ill.

FÁY Zoltán: Adalékok a Gyöngyösi Ferences Könyvtár történetéhez = Nyolcszáz esztendős a ferences rend... 2. köt. 1166-1183.

LöFfLER Erzsébet: Az Egri Főegyházmegyei Könyvtár $=$ Az egri Domus Universitatis és Líceum. Oktatás, tudomány, művészet, 
1763-2013 / szerk. Petercsák Tivadar. Eger: Líceum K., 2013. 110-149. ill.

MonOK István: A tudományos könyvtártípus kialakulása Magyarországon a korai újkorban = Szegedtől - Szegedig. 2013. 392-399.

Muckenhaupt Erzsébet: A csíksomlyói Ferences Könyvtár ősnyomtatvány-gyüjteménye 2010-ben = Nyolcszáz esztendős a ferences rend... 2. köt. 1139-1165. ill.

PÁlfi Éva: A folyóiratok titkos élete. Az Egyetemi Könyvtár periodika gyüjteménye = EgyKönyvÉvk (16.) 2013. 299-311. ill.

RózsA Dávid: Másfél évszázad - élő örökség. Mérföldkövek a Központi Statisztikai Hivatal könyvtárának történetében $=$ Tud. Müsz. Táj. (60.) 2013. 10. 411-420. ill.

Schmelczer-PohánKa Éva: A Pécsi Püspöki Könyvtár története, 1774-1945. Pécs: PTE Egy. Kvt., 2012. 370 p., 24 t. ill. (A Pécsi Egyetemi Könyvtár kiadványai; 10.)

16. század

EMöDI András: Gyöngyösi ferences könyvek XVI. századi possessorai a Szatmári Római Katolikus Egyházmegye Műemlékkönyvtárából $=$ Nyolcszáz esztendős a ferences rend... 2. köt. 1184-1204.

\section{7. század}

KNAPP Éva: A budapesti Egyetemi Könyvtár 1635 előtti ősállományának újabb húsz kötete = EgyKönyvÉvk (16.) 2013. 55-103. ill. KNAPP Éva: Otrokocsi Foris Ferenc könyvtárának kötetei a budapesti Egyetemi Könyvtárban = MKsz (129.) 2013. 1. 99-105.

18. század

CsÁki Árpád: Pálos misszió Háromszéken a 18. században. Az illyefalvi rendház és könyvei. Kiad. a Székely Nemzeti Múzeum. Sepsiszentgyörgy: Székely Nemzeti Múzeum, 2013. 100 p. ill. (Székelyföldi könyvgyüjtemények; 1.)

LUDÁNYI Gabriella: Az épület freskói $=$ Az egri Domus Universitatis és Líceum. Oktatás, tudomány, müvészet, 1763-2013 / szerk. Petercsák Tivadar. Eger: Líceum K., 2013. 70-109. ill.

Egri Főegyházmegyei Könyvtár

ORBÁN János: ,, ...kétfelől galériája lesz, a közepe pedig templom formára felmegyen.” A Teleki Téka hosszházas terveiröl = Táguló horizont. Tanulmányok a fiatal müvészettörténészek marosvásárhelyi konferenciájának előadásaiból / szerk. KovÁcs Zsolt, OrBÁN János. Marosvásárhely-Kolozsvár: Erdélyi Múzeum-Egyes., 2013. 91-109. ill.

PÁKozdi Éva Szilvia: A veszprémi piarista könyvtárak adományozói. 1. Perczel Imre $\mathrm{SchP}=$ Veszprémi Szle (15.) 2013. 4. 75-85. ill.

\section{8-19. század}

BÖsZÖRMÉNYI István: A volt losonci református gimnázium könyvtáráról = Gömörország (14.) 2013. 3. 24-27. ill.

\section{9. század}

KAZIMIR Edit: Az Egyetemi Könyvtár története a Pesti Napló hasábjain = EgyKönyvÉvk (16.) 2013. 104-169.

\section{9-20. század}

KovÁcs Nándor Erik: Vámbéry Ármin és az Akadémia Könyvtára = MTud (174.) 2013. 8 . 918-925. ill.

Megjelent még: Vámbéry Ármin, 1832-1913. Tanulmányok Vámbéry Ármin halálának 100. évfordulóján / szerk. HazAI György, Fodor Pál. Bp.: Akaprint, 2013. 22-29.

ZÁGOREC-CsuKa Judit: Magyar könyvtári tevékenységek Lendván a 19. század végétől a 20. század közepéig. Egyesületi, iskolai és népkönyvtárak Lendván = Naptár 2013. [2012.] 105-116. ill.

Megjelent még: Muravidék. Adalékok a szlovéniai magyarok nyelvéhez és kultúrájához / szerk. Gasparics Judit és Ruda Gábor. Pilisvörösvár: Muravidék Baráti Kör Kult. Egyes., 2013. 69-79. 
20. század

BARTHA Ákos: A könyv útja „,a néphez”. Hatalmi attitűdök és olvasási szokások a 20. századi Magyarországon $=$ Kommentár (7.) 2013. 6. 28-38.

BELOVÁRI Anita: „Valljuk meg ... a falunak nem is igen van viszonya a könyvvel". Népkönyvtárügy a két világháború között $=$ Acta Scientiarum Socialium 2012. 37. 101-108.

A József Attila Városi Könyvtár történetének képeskönyve, 1963-2013. [Elektronikus dok.] / szerk. Kereki Judit, Kiss Gábor, Nitsch Erzsébet. Szöveg és képek. Zalaegerszeg: Deák F. M. és Vár. Kvt., 2013. 1 CD-ROM

Kolozs Barnabásné: Önképzőköri könyvtár a veszprémi piarista gimnáziumban. A felső ifjúsági és az önképzőkör könyvtárának jegyzéke, 1935 = Veszprémi Szle (15.) 2013. 3. 48-62.

NÉMETH Gábor: A zirci müemlékkönyvtár 60 éve az Országos Széchényi Könyvtár gondozásában 1953-2013 = KKK (22.) 2013. 8. 32-37.

SAS Péter: Kelemen Lajos levele az erdélyi könyvtárak RMK anyagáról, 1958 = MKsz (129.) 2013. 1. 77-94.

Sipos Anna Magdolna: Public library vagy népkönyvtár Magyarországon $=\mathrm{A}$ debreceni népmüvelö-könyvtáros képzés jubileumi évkönyve, 1963-2013: 50 év / szerk. GodA Éva, Suppné Tarnay Györgyi. Debrecen: Debreceni Ref. Hittud. Egy., 2013. 60-68.

SIPos Anna Magdolna: Wlassics Gyula szerepe a magyar könyvtárügyben a századfordulót követö évtizedekben [1-3.] = KF (23.) 2013. 1. rész: 1. 91-114.; 2. rész: A stagnálás évei, a válságjelek és tervek a kezelésükre, 1908-1914. 2. 293-309.; 3. rész: A háborús évek. 3. 485-499.

Sonnevend Péter: A sztálini önkényuralom áldozata: a szovjet közkönyvtárak a második világháborúig, 1928-1941. 1. rész $=\mathrm{KF}$ (23.) 2013. 4. 785-799.

SzŐTs Zoltán Oszkár: Egy elfelejtett kísérlet az Országos Széchényi Könyvtár volt első világháborús gyüjteménye $=$ Tavaszi Szél, 2013. Konferenciakötet / szerk. KerESzTES
Gábor. rend. Bp.: Doktoranduszok Orsz. Szöv., 2013. 1. köt. 126-131.

SzŐTs Zoltán Oszkár: „Szerencsém van a tekintetes parancsnokságot felkérni...”. Az Országos Széchényi Könyvtár levelezése az első világháborús katonai tábori újságok beszerzése tárgyában = Esemény és narratíva... 252-269.

\section{Bibliofília, magánkönyvtárak}

Berecz Ágnes: Ráday Gedeon, a könyvgyüjtő életmüve $=$ Confessio (37.) 2013. 4. A 2011-es népszámlálás református tanulságai. 35-40. ill.

Bitskey István: Pázmány-relikviák a budapesti Egyetemi Könyvtárban = MKsz (129.) 2013. 2. 242-244.

Csı́ós Júlia: Adalékok Ráday Eszter könyvtárának rekonstrukciójához $=$ Acta Siculica 2013. 443-474. ill.

Csorba György: Kmety György könyvhagyatéka a Magyar Tudományos Akadémia Könyvtárában = HK (126.) 2013. 3. 839-853.

CzEgLÉDI László: Könyv és müvelődés a radványi kastélyban $=$ A könyvtártörténettől a jövő internetéig. Tanulmányok a 70 éves Bényei Miklós köszöntésére / szerk. BoDA István. Debrecen: DE, 2013. 107-115.

ElBe István: „Hódoló tisztelettel...”. Dedikált könyvek és levelek Kossuth Lajos könyvtárából = Esemény és narratíva...121-131.

EMŐDI András: Patachich Ádám nagyváradi könyvtárának történetéhez $=$ Szín, játék, költészet... 61-64.

Halmos Károly-Sebök Richárd: Hild József könyvtára. Rövid ismertetés és konkordancia = Tanulmányok Budapest múltjából 2013. 38 . 57-114. ill.

KLINDA Mária: Újabb adat Oláh Miklós esztergomi érsek és Thurzó György nádor könyvtárához = MKsz (129.) 2013.4. 477-479. ill.

KNAPP Éva: Ismeretlen XVII. századi könyvjegyzék a budapesti Egyetemi Könyvtár egyik ősnyomtatványában = MKsz (129.) 2013. 3. 362-364.

KNAPP Éva: Pázmány Péter magánkönyvtára = MTud (174.) 2013. 8. 852-859. ill. 
„Könyvim az én fiaim”. Vitkovics Mihály könyvtára / feldolg. és szerk. Csepregi Klára, Bor Kálmán. Bp.: OSZK-Gondolat, 2013. 288 p. ill. (Nemzeti téka)

Monok István: Nyelvi és tartalmi változások a 18. századi arisztokrata könyvtárakban Magyarországon. Szempontok és példák = Szín, játék, költészet... 65-72.

NÉMETH András: Egy bécsi bibliofil 1525-ös látogatása a budai királyi könyvtárban. Johannes Alexander Brassicanus hagyatéki leltára, $1539=$ MKsz (129.) 2013. 3. 282-305.

OrBÁN János: Portrék a könyvek között $=$ Ars Hungarica (39.) 2013. Supplementum. Tanulmányok Kelényi György tiszteletére. 172-180. ill.

Teleki Téka (Marosvásárhely)

Szende Ákos: Karl János természetrajz-szakos piarista tanár könyvtára a ,trianoni időkből” = Piarista eszmék és sorsok a 20. századból. Tanulmányok / Szende Ákos. Bp.: Piarista Rend M. Tartománya, 2013.9-28. ill.

SzILÁGYI András: Jegyzék Esterházy Miklós herceg (1765-1833) könyveiről, 1834-ből = Als ich can. Tanulmányok Urbach Zsuzsa 80. születésnapjára / szerk. GAYLHOFFERKovÁcs Gábor, Székely Miklós. Bp.: CentrArt, 2013. 177-183. ill.

VEsZPRÉMY László: „Történetünk küllőibe merész kézzel bele markola". Gentilis bíboros magyarországi olvasmányaihoz $=$ Ars Hungarica (39.) 2013. 2. Liber decorum. Wehli Tünde köszöntése 2. 230-235.

VISKOLCZ Noémi: A mecenatúra színterei a föúri udvarban. Nádasdy Ferenc könyvtára. Szeged: SZTE; Bp.: Historia Ecclesiastica Hungarica Alapítvány, 2013. 776 p. ill. (A Kárpát-medence koraújkori könyvtárai; 8.)

ZvArA Edina: Nyugat-dunántúli protestáns lelkészek könyvei a késő humanizmus korában. Szeged: SZTE; Bp.: Historia Ecclesiastica Hungarica Alapítvány, 2013. 500 p. ill. (A Kárpát-medence koraújkori könyvtárai; 9.)

\section{Olvasástörténet}

AJKAY Alinka: Egy hipotézis és néhány bizonyság = Pázmány nyomában. Tanulmányok Hargittay Emil tiszteletére / szerk. AJKAY Alinka, BAJÁKi Rita. Vác: Mondat, 2013. 13-17. ill.

Pázmány Péter: Tíz bizonyság

Dejcsics Konrád: Utazások egy Nagy Szent Gergely-kódex körül. Megfontolások a Dialógusok könyvének 7-11. századi recepciójáról = Collectanea Sancti Martini (1.) 2013. 1. 11-28.

FAZAKAS Gergely Tamás: Pásztázó könyvolvasás és kegyességgyakorlás. A Praxis pietatis margószövegeiről és egy tágabb kutatás lehetőségeiről $=$ Nyelv, lelkiség és regionalitás... 146-168.

HoRVÁTH József: A 18. századi kisalföldi hagyatéki iratok mint vallásos olvasmányok kutatásának forrásai $=$ Népi vallásosság a Kárpát-medencében, 8. Konferencia Balatonfüreden, 2009. október 1-3. / szerk. PILIPKó Erzsébet. Veszprém: Laczkó D. Múz., 2013. 207-220.

HuDI József: A helytörténet, honismeret olvasóközönsége Veszprém vármegyében 1860-ban = A kultúra vonzásában. Egy életút párhuzamai. Tanulmányok dr. Csiszár Miklós 70. születésnapjára / szerk. TölgyesI József. Veszprém: Veszprémi Szemle Várostört. Közhasznú Alapítvány, 2013. 88-95.

Keresztes Hajnalka: A Tolna megyei német reformátusok vallásos olvasmányaiból = Mediárium (7.) 2013. 1/2. 37-60. ill.

MonoK István: A magyarországi és erdélyi arisztokrácia és a „mindenkinek szóló könyv” a 17-18. században $=$ MKsz (129.) 2013. 4. 448-455.

NAGY Ildikó: Könyvkiadók, könyvek, olvasók a 20. század elejének Budapestjén $=$ Utak és útkereszteződések. Ünnepi tanulmányok M. Kiss Sándor tiszteletére / föszerk. KAHLER Frigyes; szerk. BANK Barbara. Bp.: Történelmi Ismeretterjesztő Társulat Egyes., 2013. 505-512.

OLÁH Róbert: Egy református lelkész könyves műveltsége. Apáti Madár Miklós olvasmá- 
nyai. [1-2.] = MKsz (129.) 2013. 1. rész: 2. 145-164.; 2. rész: 3. 322-335.

PoGÁNY György: „Honleányok” és a könyvek. Leányolvasók és leányolvasmányok a reformkorban $=\mathrm{KN}$ (15.) 2013. 1. 43-55.

\section{A múlt neves könyvtárosai, bibliográfusai, újságírói}

BÉNYEI Miklós: Kovács Máté elmaradt előadása az IFLA budapesti kongresszusán, ,A könyvtárosképzés rendszere Magyarországon" = KF (23.) 2013. 3. 501-519.

BognÁr Szabina: Tagányi Károly a Magyar Gazdaságtörténeti Szemle élén, 1894-1901 = Ethnographia (124.) 2013. 3. 273-296.

ELBE István: Dr. Somkuti Gabriella, 1929-2013 = KF (23.) 2013. 4. 777-778.

Fabó Edit: Dr. Czeke Marianne: az Egyetemi Könyvtár első könyvtárosnője $=$ EgyKönyv Évk (16.) 2013. 170-206. ill.

FARKAS Gábor Farkas: Kulcsár Péter, 1934-2013 = MKsz (129.) 2013. 1. 115-116.

GECSÉNYI Lajos: Kosáry Domokos, a magyar történeti bibliográfia megteremtője $=$ MTud (174.) 2013. 12. Kosáry 100. 1452-1457.
Gráberné Bösze Klára: „Mädchen für alles”. 140 éve született Czeke Marianne, az első magyar könyvtáros hölgy $=\mathrm{KN}$ (15.) 2013. 2 . 8-22.

HuHÁk Heléna: „Egy sötét lelkü sajtóbriganti”. Dövényi Nagy Lajos portréja = Kommentár (7.) 2013. 6. 61-75.

KirÁly Péter: Kulcsár Péter (1934-2013) = ItK (117.) 2013. 2. 236-241.

LENGYel András: Viczián János, 1940-2013 = MKsz (129.) 2013. 4. 523-524.

Mezey László Miklós: Batári Gyula, 1933-2013 = KKK (22.) 2013. 11. 50-51.

PogÁNYNÉ Rózsa Gabriella: Könyvek és peregrináció: Johann David Köhler (1684-1755) nézetei $=$ KN (15.) 2013. 4. 45-65.

Portrék a Központi Statisztikai Hivatal könyvtárának másfél évszázadából / szerk. RózsA Dávid. Bp.: KSH Kvt., 2013. 40 p. ill.

Püski Sándor emlékkönyv. Egy legendás ember beszédes dokumentumai. Bp.: Püski, 2013. 234 p. ill.

SolTi László: Kosáry Domokos, az Agrártudományi Egyetem tudományszervező könyvtárigazgatója = MTud (174.) 2013. 12. Kosáry $100.1466-1479$.

HegyköZi ILona - Kollár MÁria 